\title{
Omnibus Law Copy Work Field: Benefits or Not for Workers?
}

\author{
Krista Yitawati ${ }^{1}$ Anik Tri Haryani ${ }^{2}$ \\ \{kristayitawati@ rocketmail.com ${ }^{1}$, triharyanianik@yahoo.com $\left.{ }^{2}\right\}$ \\ ${ }^{1,2}$ Merdeka Madiun University, Madiun, Indonesia
}

\begin{abstract}
This study aims to analyze the Draft Omnibus Law on Employment Copyright whether it benefits workers or not. The research method used is a normative research method by reviewing the legislation and related legal material. The Omnibus Law was made to regulated regarding simplification of business licensing, investment requirements, employment, ease and protection of MSMEs, ease of doing business, research and innovation, government administration, imposition of sanctions, land acquisition, as well as ease of government projects and economic zones. This Omnibus Law is controversial for some parties because there are those who feel disadvantaged. the Omnibus Law is formed to create legal harmony for the interests of the community can be accommodated above those of the government or other parties who intentionally do not side with the community.
\end{abstract}

Keywords: Omnibus Law, Work copyrights, Labor

\section{Introduction}

The Omnibus Law which is currently being discussed by the government is a combination of several regulations whose substance is different from one regulation into one legal umbrella (Law). Conceptually, Omnibus Law is a legal product that has been implemented by several countries in the world, including the United States, Ireland, Singapore and Canada. The description of the application of this omnibus law in the preparation of regulations, has been practiced since 1970, more clearly explained as follows: "omnibus legislation has "proliferated" since the 1970s" [1]. The Academic Drafting Team of the Draft Employment Copyright Bill, in principle, is as follows: "Omnibus law is a practice of drafting legislation, which is mostly carried out in countries that adopt the common law / anglo saxon system such as America, Canada, the United Kingdom, Philippines and others. The process is called omnibus legislating and the product is called omnibus bill. The word omnibus comes from Latin which means everything or everything (for everything)" [2].

According to the Constitutional Law Expert Fahri Bachmid in the world of legal science, the concept of "omnibus law" is a concept of legal products that functions to consolidate various themes, materials, subjects and legislation in each different sector to become one large legal product and holistic [3].

Jimly Asshiddiqie, defines basically as follows: "namely the law that reaches a lot of material or the whole material of other laws that are interrelated, both directly and indirectly. This kind of practice is certainly not uncommon in the 'civil law' tradition but is forever seen as good and continues to be practiced today as the "Omnibus Law" or the Omnibus Law" [4].

Some of the objectives of establishing the Omnibus Law include: 
a. Overcoming conflicts of laws and regulations quickly, effectively and efficiently;

b. Uniforming government policies both at the central and regional levels to support the investment climate;

c. Licensing management is more integrated, efficient and effective;

d. Able to break the long bureaucratic chain;

e. Increased coordination relationships between related agencies because it has been regulated in an integrated omnibus regulation policy;

f. There is guaranteed legal certainty and legal protection for policy makers [5].

The government is currently drafting 2 (two) regulatory simplification packages, including the Draft Law on Employment and Draft Taxation Law for Strengthening the Economy. President Jokowi's government identified at least 74 laws that were affected by the Omnibus Law. One of them, which triggered many protests by workers is the Labor sector, namely the Employment Copyright Bill. In the labor sector, the Government plans to delete, amend and add articles related to the Manpower Act. The conception of the omnibus law is considered an appropriate solution for the simplification of regulations and the concept of a constructive method for drafting legislation without overruling the order in Law Number 15 of 2019 concerning Amendments to Law Number 12 of 2011 concerning Formation of Laws and Regulations. This research is expected to be able to analyze whether the Omnibus Law Bill on Employment Creation is beneficial or not for workers / laborers?

\section{Methods}

The research method that the writer will use in this research is the normative legal research method, where this method is used to find concrete law that is suitable to be applied in order to solve a particular legal problem. Namely to be able to obtain legal material to find out and analyze problems that arise regarding the position of capital market investors in the event of bankruptcy in issuers and their forms of protection. In this study, the approach used is the statute approach and the conceptual approach approach).

The statute approach is carried out by examining all laws and regulations relating to the legal issues being addressed. The facts are related to the laws and regulations that govern them and those that still apply. The laws and regulations used in this study are the Draft Omnibus Law on Work Creation, Law Number 15 of 2019 concerning Amendments to Law Number 12 of 2011 concerning Formation of Laws and Regulations, and Law Number 13 of 2003 concerning employment. After the statute approach method, the approach used next is the conceptual approach. Conceptual approach (conceptual approach) departs from the views and doctrines that develop in the science of law. In this paper, the conceptual approach used is the views and doctrines in law related to the omnibus law and labor law.

To solve a problem statement, research sources are needed. These sources can be divided into 2 (two), namely primary legal materials and secondary legal materials. Primary legal material is an authoritative legal material, meaning that it has power. Primary legal materials consist of legislation, official records or minutes in the making of legislation, and judges' decisions. The sources of primary legal materials in this study include the Draft Omnibus Law on Work Creation, Law Number 15 of 2019 concerning Amendments to Law Number 12 of 2011 concerning Formation of Laws and Regulations, Number 132003 About Employment. Secondary legal materials used in this study include literature books, legal dictionaries, legal journals. In this study, all legal materials, both primary and secondary legal sources are analyzed using the deductive method, which is a method that analyzes legal provisions as a general matter and then conclusions are drawn specifically. 


\section{Results and Discussion}

The Draft Employment Copyright Law that will be published in the context of the omnibus law, which is one Act which at the same time revises several laws. Omnibus of employment law will contain several regulated matters (11 clusters) including the licensing of business permits, ease of doing business, land acquisition, investment requirements, research and innovation support, ease of government projects, employment, government administration, economic zones, facilities and protection UMK-M and the imposition of sanctions. The ease of investment, the impact of which is creating employment, is still hampered by the complexity of licensing that applies in Indonesia. This is also the case for new ventures undertaken by beginners, which are hampered by the complexity of the bureaucracy for licensing.

Although the purpose of the Omnibus Law is Employment Creation to invite investment, increase entrepreneurship and make it easier for people to get a job, not all people see it positively. This is proven by the existence of various demonstrations against the omnibus of labor copyright, especially from the aspect of employment. Many observers point out that the Omnibus Law is an order law from entrepreneurs or capital owners that makes it easy for entrepreneurs and capital owners to more freely control the natural resources of this country.

On the contrary, this Omnibus Law does not favor the welfare of the people including workers, for example the alleged articles in the Omnibus Law that abolish halal certification and sharia regulations, abolition of minimum wages, the elimination of various leave (such as marriage leave, menstruation, childbirth, worship, and family leave), removal of environmental permit and environmental impact analysis. In addition, there are those who argue that the omnibus law will not increase investment, but instead will reduce the level of welfare of the workers, so that they become poor who will only eliminate the minimum wage, eliminate severance pay, outsourcing and free employment contracts (labor market flexibility), until the entry of unskilled TKA, the issue of loss of social security, and the elimination of criminal sanctions for employers who do not provide labor rights [6].

Under current conditions, where a Covid-19 pandemic was detected by April 23, 2020, more than 2,000,000 cases of Covid-19 have been reported in more than 210 countries and regions, resulting in more than 195,755 people dying and more than 781,109 people recovering [7]. This pandemic besides causing health problems has also caused global socioeconomic disruption, which the International Labor Organization (ILO) noted, as much as 81 percent of the global workforce totaling around 3.3 billion, or 2.67 billion workers are currently affected by workplace closure due to pandemic corona virus (Covid-19). While 1.25 billion workers are threatened with termination of employment [8]. In Indonesia too, the COVID-19 virus pandemic outbreak "has forced the government" to issue a special policy calling for a temporary halt to activities that cause crowds, such as educational activities in schools, work in companies, activities in public spaces, to religious in places of worship. The wave of layoffs in Indonesia during the co-19 pandemic caused the number of laid-off workers laid off by $2,084,593$, where in the formal sector it was laid off reaching $1,304,777$ and layoffs reaching 241,431 while in the informal sector 538,385 informal workers lost their jobs [9]. Then what about the fate of the workers or employees who were laid off? During this time, if there is a case of layoffs, the company is responsible. Pay employee severance according to work period. In the future, apart from severance pay, employees who lose their jobs due to layoffs will receive a guarantee from the government. In the draft of the Employment Copyright Bill in article 46A reads:

a. Workers / laborers who are laid off are entitled to a guarantee of losing their jobs

b. JKP is organized by the Manpower Social Security Organizing Agency (BPJS).

"JKP will be given to workers / laborers who are BPJS Employment participants and actively pay contributions," Article 46C reads. 
In Article 46D, JKP benefits will be stipulated to be received by workers who were laid off, namely in the form of:

a. Training and certification

b. Cash

c. Placement facility.

"So the benefits of JKP, the government will provide training (work), provide pocket money for 6 months, and work placement. This is specifically for employees whose companies go bankrupt or are laid off (not due to criminal acts) and actively pay BPJS Employment contributions. Likewise with the amount of severance received by workers if they are laid off is greater than the Labor Law No. 13 of 2003 also mentioned in the Employment Copyright Bill, which is in the form of bonuses or awards. The Employment Copyright Omnibus Bill also regulates the provisions of holidays or rest periods for workers. Mentioned in Article 79:

1) Break time between work hours, at least half an hour after working for 4 hours continuously. This break does not include working hours

2) Weekly breaks 1 day to 6 working days a week.

If seen in the Manpower Act No. 13 of 2003 it is written that the weekly rest allowance can be 1 day for 6 working days or 2 days for 5 working days a week. While for the same annual leave, given a minimum of 12 working days after 1 Year work period. With the pros and cons that occur in the community related to the Omnibus Law which has a broad reach, it is necessary to do a deeper study and trial process first. Moreover, the Omnibus Law will abort about 72-74 articles which are considered problematic in the employment and taxation sectors. For this reason, the central government of both the President and the Parliament needs to take the right steps before implementing the Omnibus Law as a legal umbrella. It also requires a team of experts who have been accredited in the field of law to be able to explain the concept of applying Omnibus Law both to local governments and the community so that misunderstandings do not arise. Thus, the preparation of the Omnibus Law will be more efficient because there are many elements involved, ranging from policy makers, academics, government and legal practitioners.

Explain the definition of Omnibus Law to the public as a legal product that aims to harmonize the law so that the principle of its usefulness is more felt in the community. The government must be able to convince the public that the Omnibus Law is formed to create legal harmony so that the interests of the community can be accommodated above those of the government or other parties who deliberately do not side with the community. Therefore, the principle of usefulness of this legal product must be clear and reach the public. The Omnibus Law must also clarify workers' rights so as not to create new problems. Especially now that the Omnibus Law is busy getting rejected by the workers because they think the minimum wage will be disrupted. For this reason, the Omnibus Law must be made one of them to protect work rights and labor costs. Some things that can be done are by making special rules for social security for workers and minimum wages that are more pro labor. The goal is to improve the SJSN (National Social Security System) and labor BPJS regulations, which have still been problematic in their application. The involvement of labor groups in the discussion of the Omnibus Law Bill in the Employment Creation sector is also important so that the aspirations of labor groups are conveyed to the government. Related to this, the public, especially workers, should not be in a hurry to prejudice negatively on the omnibus law that is being drafted and we should support the government's steps in resolving the complicated regulations in Indonesia in investing so as to foster economic growth and open up employment opportunities. 


\section{Conclusions}

The draft Omnibus Law aims to be able to unravel the complexity of the existing regulations and enhance the development of the national economy, which specifically will improve every regulation in the economic field which includes Investment, Taxes, Development, as well as the Availability of Employment, this will certainly have a positive impact on Indonesian society, especially business people and workers. But in the course of many pros and cons in criticizing the work copyright omnibus bill, therefore the Government deserves to hear the aspirations of various community groups, especially laborers. With this engagement, the labor group can voice their aspirations in a healthy manner and study critically, but these aspirations should not be channeled with counterproductive street actions but channeled through critical studies as input in the preparation of work copyright omnibuses.

\section{Acknowledgments}

The author would like to thank the Merdeka Madiun University for funding the author's participation in this international conference and thanks the Faculty of Law Universitas Negeri Semarang for providing facilities to join this International Conference.

\section{References}

[1] Glen S. Krutz, Hitching a Ride: Omnibus Legislating in the U.S. Congress 12 ; see also Sinclair, Unorthodox Lawmaking (4th ed.), supra note 27, at 154 (2001).

[2] Academic Manuscript Draft Employment Copyright Act, p. 24 (2020).

[3] Bagir Manan, Some Indonesian Constitutional Law Issues, (Bandung: Alumni), p. 144, (1997).

[4] Jimly Asshiddiqie, law), Administrative simplification, Omnibus Act (omnibus legislation, and codification https://www.jimlyschool.com/bac a / 34 / uu-om nibus -omnibus -law - simplificationlegislation-and-codification-administrative accessed 2 June 2020.

[5] Firman Freaddy Busroh, "Omnibur Law's Conceptuality in Resolving Land Regulation Problems", Arena Hukum, Vol. 10, No. 2, p. 247 (August 2017).

[6] Ahmad Ulil Aedi, Volume 14, Number 1, March 2020: 1-18, National Journal of SINTA Accreditation 2 Decree of the Ministry of Research, Technology and Technology: No: 34 / E / KPT / 2018, e-ISSN: 2579-7425 (online), https: / /jurnalintigma.net/2020/01/15/pessnya-omnibus-law-ciptalanganangan-kerja/ accessed on 12 June 2020.

[7] Coronavirus COVID-19 Global Cases ". Johns Hopkins University. Accessed March 20, 2020

[8] https://jurnalsecurity.com/dampak-covid-19-ilo-125-billion-workers-in-the-world-threatened- phk/, accessed June 10, 2020.

[9] Ministry of Manpower Public Relations Bureau, accessed on April 20, 2020 